\title{
The Defense of Entrapment Re-examined
}

\author{
C. Jeddy LeVar \\ Henderson State University
}

Abstract: This note is an introduction to the problem of entrapment in the enforcement of vice law's. Supreme Court decisions based on federal law are used as the model for a discussion of the concept of entrapment. Entrapment occurs when "otherwise innocent" persons are lured into crime by inappropriate police conduct. A minority view on the Court is that regardless of defendant characteristics, the entrapment defense should be allowed anytime the police instigate crime. Political scientists' interest in entrapment law stems from (1) the law's impact on police behavior and (2) the constitutional issue of due process surrounding crime encouraged by government officials.

A re-examination of the legal defense of entrapment is timely and relevant in response to popular concern about narcotics, abortion, homosexuality, and other vice laws. Laws prohibiting vice or "victimless" crimes have been criticized for the impact which they have on police methods. ${ }^{1}$ Since vice crimes ordinarily produce no citizen complainants, the police act as the complainants. They use infiltrators, decoys, informers, and undercover agents to obtain evidence about vice activities. When undercover agents purchase narcotics and then arrest the seller, the defense often claims that the law enforcement officials enticed the defendant into committing the crime, thereby entrapping him.

The U.S. Supreme Court has recognized the legitimacy of an entrapment defense in federal law. However, it has refused to adopt the view that entrapment constitutes an infringement of the constitutional guarantee of due process. ${ }^{2}$

Three justices tried to get the Court to declare a Constitutional right against entrapment in 1932 in Sorrells v. United States. However, the majority based the entrapment defense on statutory grounds: 
We are unable to conclude that it was the intention of Congress in enacting this statute that its processes of detection and enforcement should be abused by the instigation by government officials of an act on the part of persons otherwise innocent in order to lure them to its commission and to punish them.

The Court distinguished otherwise-innocent persons who are lured by government agents with "repeated and persistent solicitation" from unwary criminals who are merely given "opportunities or facilities for commission of the offense." In reversing Sorrells' prohibition-related conviction, the Court pointed out that the undercover agent had made three requests for the liquor before the defendant capitulated and obtained some for the agent.

Thus two factors are considered in weighing the merits of an entrapment defense. The first focuses on the actions of the law enforcement personnel. Repeated solicitation by the agents supports an entrapment claim. The second focuses on the defendant, requiring that he be an otherwise-innocent person. If a defendant is already engaged in relevant criminal activity prior to the solicitation by government agents, he may not be considered an otherwise-innocent person. In such cases defendants are said to have been predisposed to commit the crime.

This distinction between otherwise-innocent and criminally predisposed defendants reflects the philosophy that persons lured into crime by government officials are not as guilty as persons already engaged in crime who are just given one more opportunity by government to break the law.

In their separate opinion in Sorrells, Justices Roberts, Stone, and Brandeis attacked that assumption. They argued that breaking the law constitutes a crime regardless of what the prior criminal activity of the accused is. They contended that the only factor which should be considered in an entrapment claim is the behavior of the police. They said that the constitution forbids prosecution of anyone for a crime which the government instigates, whether by repeated solicitation or not. In their dissent the three insisted that "the courts must be closed 
to the trial of a crime instigated by the government's own agents."

\section{Holding the Line}

Over the years the U.S. Supreme Court has held the line on its approach to entrapment, in spite of strong minority dissents. In 1958 the Court reaffirmed its approach to entrapment in reversing a conviction in a narcotics case. In this case the defendant was an addict who was undergoing treatment to kick the habit. He was repeatedly asked by an undercover agent to get a drug before he finally gave in and made the purchase.

Whether there was a majority on the bench which was willing to change the approach is not clear, though. The attorneys in the case did not ask for a re-examination of the doctrine of entrap-ment, and "we do not ordinarily decide issues not presented by the parties," pointed out Chief Justice Warren in his five-man majority opinion which did not re-examine the approach taken in Sorrells. ${ }^{4}$

In contrast to the majority's self-restraint, Justices Frankfurter, Douglas, Harlan, and Brennan urged the Court to plow new ground. They revived the arguments in the Sorrells dissent, calling for a constitutional basis for entrapment which focuses on the conduct of government officials. As they saw it the question should be: Does "the police conduct ... fall below the standards, to which common feelings respond, for the proper use of governmental power?"

After the 1958 Sherman case, some lower federal courts did adopt the position advanced in the minority opinion, perhaps as a result of the ambiguity in an opinion which refused to address the issue which the minority discussed. In United States v. Bueno ${ }^{5}$ the fifth circuit court of appeals held that regardless of predisposition, entrapment occurs whenever the government supplies contraband to defendants. In 1971 the ninth circuit court of appeals reversed a conviction because a government agent was so enmashed in the criminal activity that prosecution of defendants was said to be repugnant to the criminal justice system. ${ }^{6}$

Any ambiguity over the Court's attitude toward 
entrapment was cleared up two years later, however, when a new court sporting four personnel changes decided United States v. Russell.?

\section{United States v. Russell}

In the Russell case the defendant, Richard Russell, was approached by an undercover agent for the Federal Bureau of Narcotics and Dangerous Drugs. The agent claimed to represent an organization that wanted to control the manufacture and distribution of methamphetamine (speed). He offered to supply Russell and two co-defendants, John and Patrick Connolly, with an essential ingredient which was difficult to obtain in return for half the speed produced. During the conversation, Patrick said he had been manufacturing speed for eight months. John showed the agent a bag of the drug which he said came from "the last batch we made." During two visits to the laboratory, the agents saw bottles bearing the label of the same essential ingredient that he was supposed to supply, although he had not provided those bottles.

The agent witnessed the manufacture of the drug by Patrick and Russell, using the ingredient that he provided. In accordance with the agreement, he received half of the drug. Also, he bought part of the remainder from Russell for $\$ 60$. On the basis of this evidence Russell and the Connolly brothers were convicted of illegally manufacturing and selling methamphetamine. Russell's sole defense was entrapment.

The appeal was argued before the U.S. Supreme Court in February, 1973. The Court upheld Russell's conviction. Speaking through Rehnquist, the majority rejected the defendant's call for a constitutional rule that "would preclude any prosecution when it is shown that the criminal conduct would not have been possible had not an undercover agent supplied an indispensable means to the commission of the crime that could not have been obtained otherwise, through legal or illegal channels." The majority went on to contend that even if they had accepted that argument, Russell would not have benefited from it since the record showed that empty bottles of the essential 
ingredient were found in the laboratory and that the government agent had not supplied them. Thus the agent would not have been an "indispensable means" to the commission of the crime.

The Court's rationale on whether the agent was an "indispensable means" to the crime is troublesome in light of its failure to inquire where those other bottles came from. The methods which are commonly used in narcotics investigations suggest that it is possible that some other, unrevealed undercover agent might have been the source of the empty bottles. Their presence in the lab then would not necessarily mean the ingredient was obtainable from nongovernment sources.

Another problem with the approach which focuses on the defendant's predisposition is that the court treats the person predisposed to crime as an unwary criminal. But what makes him a criminal, his predisposition, or a criminal act? The prosecution did not prove that Russell had manufactured and sold methamphetamine before the undercover agent arrived on the scene. Russell's involvement in the case can be summarized as follows:

He was present at the initial meeting in his home when the agent made his offer.

Russell helped manufacture the speed with the essential ingredient (propanone) supplied by the agent. This was done in the Connolly home where the lab was located.

He kept half the drug and sold part of that to the agent.

But what about Russell's activities before the agent appeared? Rehnquist said the "defendants admitted making the drug both before and after those batches made with the propanone supplied by Shapiro (the agent)." But the Court's own record shows that it was the Connolly brothers (not Russell) who told the agent they had been making speed for eight months. Where is the evidence of Russell's prior involvement in the illegal production of drugs? The appellate court, which reversed Russell's conviction, pointed out that hearsay evidence 
had been used to establish the fact that Russell sold speed and associated with the Connollys. The Supreme Court's opinion refers vaguely to Russell's association with the Connolly brothers' ring. However, mere association with criminals does not constitute a crime.

The fact that the majority approved the use of hearsay evidence to establish predisposition is a very troublesome problem with the majority's approach. As pointed out by Justices Stewart, Marshall, and Brennan in their dissent, this means that the government may entrap a person with a criminal record or bad reputation "and then prosecute him for the manufactured crime, confident that his record or reputation itself will be enough to show that he was predisposed to commit the offense anyway."

A final point made by the majority was the practical matter that obtaining convictions for violations of drug laws requires infiltration and limited participation by government in the illegal activities. The majority argued that if defense of entrapment focused on the tactics of officials rather than on the predisposition of defendants, "it would be impossible ever to secure convictions of any offences which consist of transactions that are carried out in secret."

And that brings us back full circle to a point made at the beginning of this paper. Vice laws have been criticized because they require police to induce crime in order to enforce them effectively. But "it is the government's duty to prevent crime, not promote it." ${ }^{\circ}$ If the vice laws were repealed, promoting crime would be eliminated as an ordinary police technique.

\section{Conclusion}

Political scientists' interest in the entrapment defense stems principally from the impact that entrapment law has on police methods and the controversy over giving entrapment a constitutional basis. Additional questions which a discussion of entrapment law raises include: (1) Should vice laws be repealed because their enforcement necessitates instigation of crime by government? (2) Does the present approach to entrapment afford adequate protection from wrongful police conduct, since 
typical encounters are not witnessed and therefore no witnesses are available to testify and aid in detecting perjured testimony concerning such material facts as whether solicitation was repeated, who made the offer, etc? (3) Is use of past criminal record to establish predisposition unduly prejudicial to the defendant? (4) Is the jury's task too complicated since it must determine the predisposition of the alleged criminal as well as whether someone was lured or merely given one more opportunity to commit crime?

\section{Notes}

1. Victimless crimes are said to be consensual transactions which produce harm only to self and which are in demand from a large segment of the population. They produce no citizen complaints.

2. Sorrells v. United States, 287 U.S. 435 (1932): United States v. Russell, 93 S. Ct. (1973).

3. 287 U.S. 448 (1932)

4. Sherman v. United States, 356 U.S. 369 (1958).

5. 447 F. 2d 903 (5th Cir. 1971)

f. Greene v. United States, 454 F. 2nd) 783 (9th Cir. 1971).

7. 93 S. Ct. $1642(1973$

8. Id. at 1648 . 